\title{
Evaluating the use of Toondoo for Collaborative E-Learning of Selected Pre-Service Teachers
}

\author{
Ava Clare Marie O. Robles \\ Mindanao State University, General Santos City, 9500, Philippines \\ Email: avarobles2014@gmail.com
}

Received: 16 August 2017; Accepted: 13 September 2017; Published: 08 November 2017

\begin{abstract}
With the growing reliance on information technology, new trends were marshaled in the field of education to produce graduates endowed with $21 \mathrm{st}$ century skills. It is unequivocal that collaborative elearning encourages teachers to innovate for the enhancement of students' learning. In furtherance of the ongoing teaching-learning upgrades, this study aimed to evaluate the use of Toondoo as a tool for collaborative elearning to selected education students. Specifically, this study determined the extent to which Toondoo has promoted students' collaborative e-learning, and identified the influence of Toondoo to students' learning. Using descriptive-correlation design, results showed that students exhibit positive attitudes on the use of Toondoo. Results further revealed that Toondoo has significantly influenced students' performance, albeit they differ according to their attitudes toward the employment of Toondoo.
\end{abstract}

Index Terms - Collaborative e-learning, Pre-service, Toondoo, Mindanao State University, General Santos, Philippines.

\section{INTRODUCTION}

The incessant technology upgrade pushed various universities to employ innovative strategies, technology integration, and e-collaboration. Accordingly, the Commission on Higher Education (CHED) Memorandum Order No 46, Series of 2012 [1], mandated universities to develop productive and globally competitive students imbued with values, cognitive, technical and technological competence. This memorandum underscores the shift in pedagogy to enable learners to build up not only their cognitive skills, but also to develop awareness of their environment, collaborate, and play their social role in the community.

Collaborative e-learning is considered one means for students to be globally competitive, and to acquire the 21st century skills. Based on the study of Brunnet and Portugal [2] students in this milieu preferred new educational tools in communicating, collaborating and learning. Indeed, the fast development of technologies has brought various changes of today's learners. With this, students go to school armed with different gadgets such as laptops, tablets, i-phone and other mobile technologies. They use these devices for fun, for communicating with people as well as for storing, exchanging and managing data. As a consequence, learners indulge themselves in diverse exploration which increases their potential to do e-collaboration activities. As latest technology tools proliferate, it is vital that teachers grab their chance to integrate these tools into the classroom to improve the teaching-learning process. One means to carry out this teaching mode is by employing online tools such as Etudes, Wikis, and Toondoo as support to enhance students' competencies. With the rising dependence on the internet connectivity, Toondoo may offer teachers diverse prospects to advance students' learning appropriate to their inclinations. Moreover, this may be used as a venue for students to be socially aware, proactive, collaborative and involved in public and environmental affairs.

At the program level, the teachers' competency to integrate technologies must increase as technology advances, correspondingly. If the evolution of technology has influenced the teachers to discover the latest means to assimilate new learning, then it must boost the learning experience and promote e-collaboration among learners.

The integration of collaborative e-learning into education systems has been acknowledged and embraced worldwide as a tool to enhance teaching and learning processes [3]. Unfortunately, in Mindanao State University, General Santos City, teachers employ collaborative e-learning at a very limited level. The need to enhance students' 21 st century skills are deemed necessary. Thus, the use of Toondoo for collaborative elearning is considered imperative. Recognizing the significance of this matter, this study aimed to determine the extent of how Toondoo promotes the collaborative elearning of the students. In addition, it determined the students' attitudes toward Toondoo as well as identified whether Toondoo has significantly influenced the students' academic performance. This study can make a significant contribution to the existing body of knowledge as part of the general effort, to promote the use of Toondoo not just as a digital tool, but as a means to increase students' collaborative e-learning. 


\section{RELATED WORKS}

Technology offers different approaches for students and teachers to acquire new learning experiences. It provides latest methods for all educators and learners to be openly accountable to various audiences. In this digital world, Baranauckas [4] posited that students from different walks of life are apt to technology-related activities, making them more reliant on them. In fact, many people regard the Internet as a leading source of information. In another field, Internet is commonly employed to enhance the instructional experience and promote collaboration [5,6].

With this trend, teachers at various levels are currently challenged to innovate. Concomitantly, the use of online tools in the classroom generate stimulating chance to enhance the learning and collaboration of the students. Accordingly, Kahiigi [3] emphasized that there is a genuine need to meet the growing need for high-quality education. One means to achieve this need is through the integration of e-learning into the education system. Nevertheless, there is limited knowledge about the use of e-learning to facilitate learning. In fact, the actualization of e-learning is very limited and in some cases lacking.

Undeniably, students in this digital age need to learn how to effectively create and collaborate new information on the web through the use of different tools Robles [7]. For this reason, many educational institutions in developing countries are gradually moving towards the integration of e-learning in their curricula. The drive towards this educational intervention has been motivated by factors such as the need to support student learning, ecollaboration and access to information Kahiigi [3].

Collaborative E-Learning as defined by Salmons [8] as the construction of knowledge, negotiating meanings and solving problems through shared engagement of two or more learners in a harmonized effort using the Internet and electronic communications. The pervasiveness of the Internet is becoming a stressor to students. As emphasized by Pund [9] students become stressed because of the increasing demands that the teachers require for their students to cope.

In contrast, students can use Toondoo to share their ideas online with no stress at all. As mentioned by Education and Culture DG (2012) Toondoo is a digital comic that offers a way for students to experiment and use their skills in a way that eradicates constraints. It minimizes stress connected to productive skills because this instrument allows them to express contents confidently. Through this tool, students are empowered to share their ideas easily at the same time use it as a learning platform for e-collaboration.

Using the digital comics, students are turned into active learners. Hence, the use of Toondoo may promote students' collaborative e-learning, enabling them to become active learners. Also, Toondoo encourages students to showcase their digital comics in an e-learning environment, where teachers and students may collaborate. As disclosed by Lambropoulos, Culwin, and Romero [10], the effects of technology change learners from non-responsive recipients of information to active collaborators in looking for shared meaning. Hence, the utilization of Toondoo may serve as a stimulant for better collaboration and performance among students.

Figure 1 presents the conceptual framework of the study. The extent usage of Toondoo to promote students' collaborative e-learning is the independent variable. This frame is indicated by students' focus on task and participation; students' shared responsibility, accountability and dependability; and students' communication strategies and information sharing. The dependent variables are the level of collaborative elearning, performance in Educational Technology 1 (EdTech 105A), and students' attitudes toward collaborative e-learning. The arrow illustrates the causeeffect relationship of the variables mentioned above.

Based on more than 20 years of monitored research conducted by the International Society for Technology in Education [11] there is one convincing trend that emerged. That is, integration of technology into instruction, when implemented appropriately has positive effects on student achievement. Furthermore, the ISTE, the State Educational Technology Directors Association (SETDA), and the Partnership for 21st Century Skills had identified technology as a platform to improve students' abilities to "communicate, collaborate, create, and innovate."

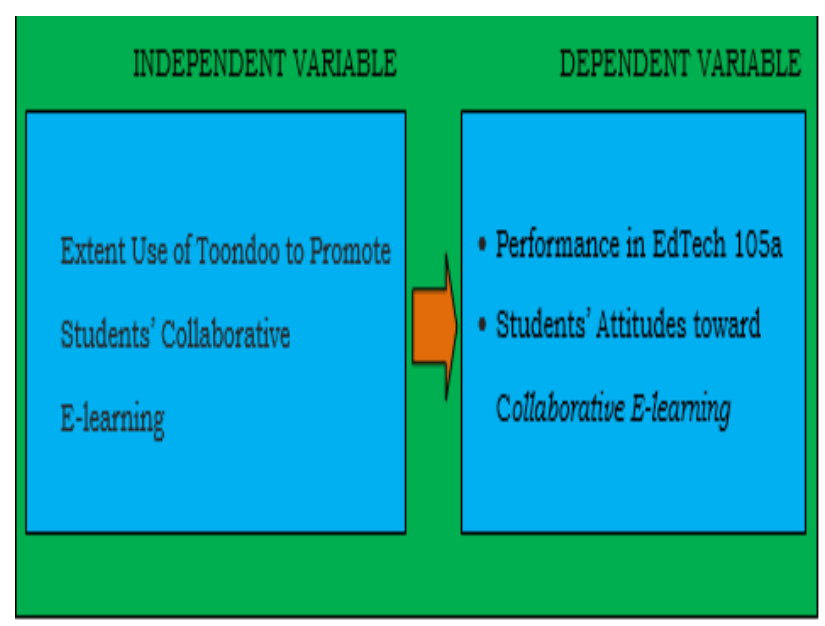

Fig.1. Conceptual Framework

As such, these technologies provide an opportunity to develop students' critical thinking skills, enabling them to collaborate with others online. Similarly, it allows students to best showcase their understanding of newly learned materials and concepts. Hence, technologies have to be integrated as ingredients to address not only the $21 \mathrm{st}$ century challenges of students; but more importantly, to imbibe proper value system and positive attitudes.

Finally, Li [12] regarded attitude as a significant predictor of students' academic achievement. Based on her research, she found out that most studies revealed that students who have a positive attitude towards their academic endeavor tend to perform well academically. Henceforth, she concluded that there was a positive relationship between attitude and academic achievement. 


\section{METHODOLOGY}

\section{A. Research Design}

The study utilized the mixed-method research design. As such, it relied profoundly on the observations, experiences, and focus group discussions (FGD) of selected key respondents. The observations and experiences of students were cross-validated with available secondary data online and other related documents. The data were then synthesized as bases for findings and conclusions, upon which implications and recommendations were formulated. The respondents of this study were the 44 purposely selected third-year students who underwent Toondoo with e-collaboration activities. They were also enrolled in Educational
Technology (EdTech105A) of Mindanao State University, General Santos City, School Year 2013-2014.

The teaching routine involved the setting of objectives and students' groupings followed by a demonstration of the Toondoo mechanics. Next, to the Toondoo conceptualization, the students' initial outputs were subjected to online collaboration, research, and documentation. After which, online construction, presentation and critiquing of Toondoo Outputs were done by students for two months. Subsequently, the students were given the slot to post their Toondoo final outputs in Weebly. At this stage, students had their chance to give their online feedback for further enhancements and suggestions. Figure 2 below describes the Toondoo development process:

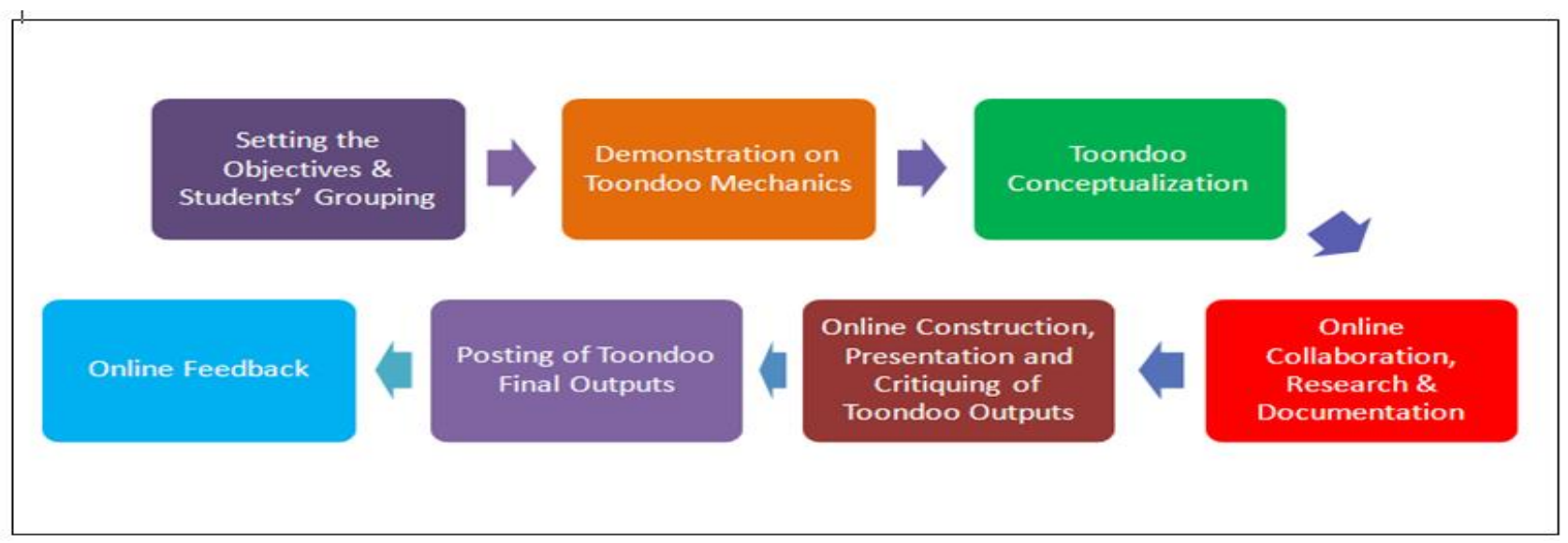

Fig.2. Toondoo for Collaborative E-Learning Development Process

\section{B. Data Gathering Tools and Analysis}

The study utilized the following qualitative data gathering tools, namely: interview guide; questionnaire and focus group discussions (FGD) among students. Facilitation and recording of interviews were also made. Findings that were drawn from the sources above were analyzed and served as the basis for the recommendation. All data gathered were computed, analyzed and interpreted using the statistical tools such as weighted mean and Pearson r. The results were interpreted using the following rating scales and qualitative description.

$\begin{array}{cc}\text { Scale } & \text { Qualitative Description } \\ 4.21-5.00 & \text { Very High Extent } \\ 3.41-4.20 & \text { High Extent } \\ 2.61-3.40 & \text { Moderate Extent } \\ 1.81-2.60 & \text { Less Extent } \\ 1.00-1.80 & \text { Least Extent } \\ & \\ \text { For the Students' Attitudes: } \\ \text { Scale } & \text { Qualitative Description } \\ 4.21-5.00 & \text { Very Positive Attitude } \\ 3.41-4.20 & \text { Positive Attitude } \\ 2.61-3.40 & \text { Moderately Positive Attitude } \\ 1.81-2.60 & \text { Negative Attitude } \\ 1.00-1.80 & \text { Very Negative Attitude }\end{array}$

To determine the correlation results between the use of Toondoo and students' performance in EdTech 105, Pearson $r$ with its corresponding verbal interpretation was utilized. The study employed the following classification adopted from Calmorin [13] as shown below:

\footnotetext{
An $r$ from \pm 0.00 to \pm 0.20 An $r$ from \pm 0.21 to \pm 0.40

An $r$ from \pm 0.41 to \pm 0.70

An $r$ from \pm 0.71 to \pm 0.90

An $r$ from \pm 0.91 to \pm 0.99

An $r \pm 1.00$
}

denotes negligible correlation denotes low relationship denotes moderate relationship denotes high relationship denotes very high relationship denotes perfect correlation

For illustration purposes, Figure 3 depicts a simple sample of students' outputs.

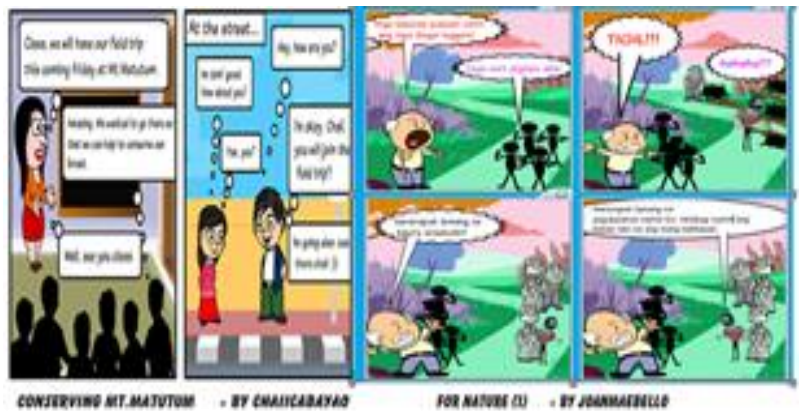

Fig.3. Sample of Students' Output 


\section{FINDINGS}

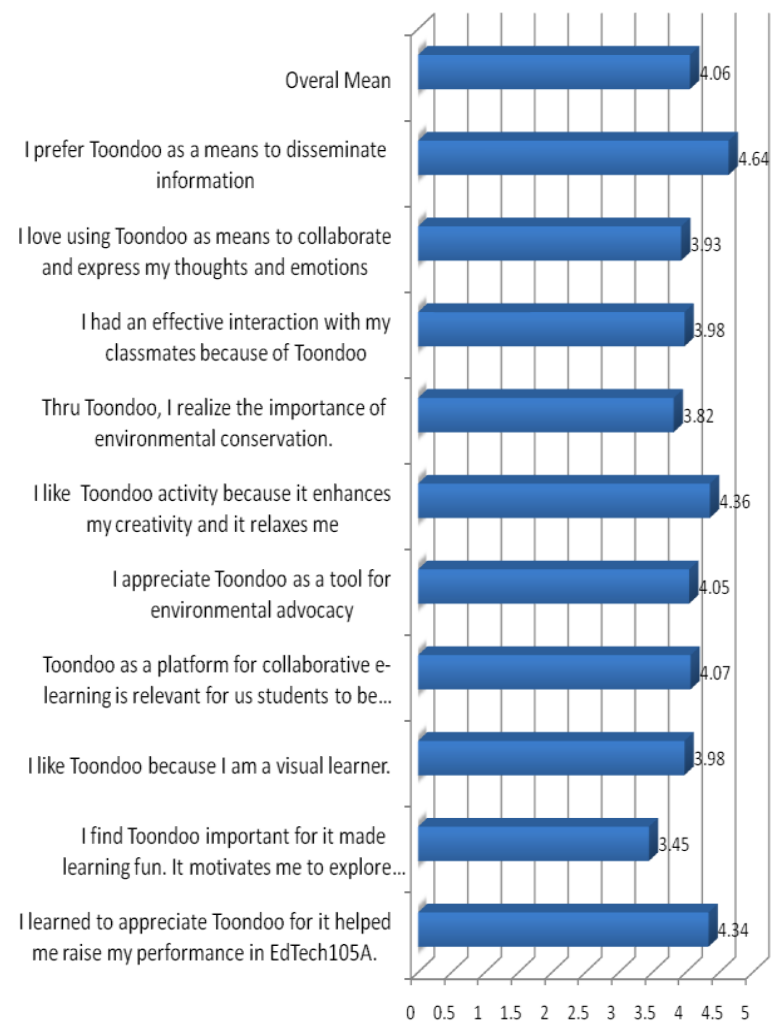

Fig.4. Shows the attitude of students toward Toondoo.

The study revealed that students have a very positive attitude in: "using Toondoo to disseminate information" $(\mathrm{wm}=4.64)$; "Toondoo activities relax and enhance their creativity" ( $\mathrm{wm}=4.36)$; and that "Toondoo is a factor that helped raise their performance in Ed105A" ( $\mathrm{wm}=$ 4.34). In general, the students have positive attitudes towards Toondoo. This result disclosed that students like Toondoo because it made their learning more fun and that they found it as a useful tool in improving their academic performance. This finding also implies that students who are good at Toondoo are active learners who have greater chance to perform better. This finding supports the study of $\mathrm{Li}$ [12] that students, who have a positive attitude towards their academic performance exert more effort compared with conventional learners. Thus, they are more likely to perform better in school.

Additionally, Table 1 presents the extent use of how Toondoo promotes collaborative e-learning. Based on the evaluation of the students, Toondoo promotes collaborative e-learning to as very high extent in "finishing their tasks with eagerness" which got the highest weighted mean of 4.61. This is followed by "tracking of assigned tasks that do not depend on others to do the online work" ( $w m=4.34)$, and "taking a turn in teaching members by the scope of practice, code of ethics, and standards" $(w m=4.25)$. On the other hand, "consistently establishing collaborative relationships with others over the Internet" got the lowest weighted mean of 3.23. These findings imply that students desired to have consistent online collaboration, but due to limited internet connectivity in the campus, they were not able to do so.

Table 1. The Extent of how Toondoo Promotes Collaborative ELearning

\begin{tabular}{|c|c|c|}
\hline & WM & Des \\
\hline \multicolumn{3}{|l|}{$\begin{array}{l}\text { A. Focus on task and participation (My } \\
\text { team and I...) }\end{array}$} \\
\hline $\begin{array}{l}\text { 1. Consistently stay focused on the } \\
\text { assigned online group tasks. }\end{array}$ & 4.18 & $\mathrm{HE}$ \\
\hline $\begin{array}{l}\text { 2. Work within the group to make sure all } \\
\text { of my group mates mastered the content. }\end{array}$ & 3.95 & $\mathrm{HE}$ \\
\hline $\begin{array}{l}\text { 3. Effectively encourage and support the } \\
\text { efforts of our group mates. }\end{array}$ & 4.11 & $\mathrm{HE}$ \\
\hline $\begin{array}{l}\text { 4. Take part in completing our group work } \\
\text { using the internet. }\end{array}$ & 3.55 & $\mathrm{HE}$ \\
\hline $\begin{array}{l}\text { 5. Develop interest and appreciation in our } \\
\text { Toondoo advocacy project. }\end{array}$ & 3.66 & $\mathrm{HE}$ \\
\hline Mean & 3.89 & HE \\
\hline \multicolumn{3}{|l|}{$\begin{array}{l}\text { B. Shared Responsibility, accountability, } \\
\text { and dependability (My team and I...) }\end{array}$} \\
\hline $\begin{array}{l}\text { 1. Consistently finish tasks with eagerness } \\
\text { based on the online activities assigned to } \\
\text { us. }\end{array}$ & 4.61 & VHE \\
\hline $\begin{array}{l}\text { 2. Demonstrate professional judgment } \\
\text { when delegating or completing tasks. }\end{array}$ & 4.23 & VHE \\
\hline $\begin{array}{l}\text { 3. Track assigned tasks that do not depend } \\
\text { on others to do the online work. }\end{array}$ & 4.34 & VHE \\
\hline $\begin{array}{l}\text { 4. Ensure that the assigned online task is } \\
\text { equally divided to each member. It is } \\
\text { understood that each of us accepts } \\
\text { responsibility for any failure we } \\
\text { committed. }\end{array}$ & 4.02 & $\mathrm{HE}$ \\
\hline $\begin{array}{l}\text { 5. Take turn teaching to our members in } \\
\text { accordance with the scope of practice, } \\
\text { code of ethics, and standards. }\end{array}$ & 4.25 & VHE \\
\hline Mean & 4.29 & VHE \\
\hline \multicolumn{3}{|l|}{$\begin{array}{l}\text { C. Communication Strategies and } \\
\text { Information Sharing (My team and I...) }\end{array}$} \\
\hline $\begin{array}{l}\text { 1. Reinforce based on the product of the } \\
\text { group and uses communication strategies } \\
\text { (verbal \& non-verbal) appropriately in a } \\
\text { diverse online situation. }\end{array}$ & 4.14 & $\mathrm{HE}$ \\
\hline $\begin{array}{l}\text { 2. Demonstrate recognition of the } \\
\text { relationship between group work and } \\
\text { quality of online inputs. }\end{array}$ & 3.98 & HE \\
\hline $\begin{array}{l}\text { 3. Consistently establish collaborative } \\
\text { relationships with others over the internet } \\
\text { through interaction, discussion, and giving } \\
\text { contribution online. }\end{array}$ & 3.23 & $\mathrm{ME}$ \\
\hline $\begin{array}{l}\text { 4. Appreciate Toondoo as a tool for it } \\
\text { promotes online collaborative learning. }\end{array}$ & 3.41 & HE \\
\hline $\begin{array}{l}\text { 5. Have a regular discussion to build each } \\
\text { other's contribution in carrying out the } \\
\text { necessary online activities. }\end{array}$ & 3.48 & $\mathrm{HE}$ \\
\hline Mean & 3.65 & HE \\
\hline Overall Mean & 3.94 & HE \\
\hline
\end{tabular}

Based on the focused group discussion (FGD), it was found out that the completed outputs of the students were restructured to specify that they have sought guidance from their peers online on how the content and the structure of their Toondoo were constructed. This is because none of them had experienced giving their personal reflection using Toondoo. While students were in the progress of completing their Toondoo, they posted 
them with their peers for evaluation and comments. This encourages social networking, a course of action that is repetitive in nature and gives feedback.

As the course ended, Toondoo evolved from a formative assessment instrument to one that was summative. At this period, students shared their Toondoo to their friends who then cross-referenced the Toondoo activities with the course objectives. Two months after the classes had ended (the following semester), ten education students were interviewed. The objective of the interview was to determine if they were still sharing or collaborating (online) with other students based on their Toondoo outputs. Results disclosed that seven out of ten students were still using Toondoo, but for other purposes. Three students stated that time and Internet connectivity were the factors why they discontinued the use of Toondoo. For example, a student commented:

"I personally made my digital comic (Toondoo) to share my feelings online. I do this mode of expression because I am more comfortable with it (kung mag tira ug tao). I am excited as always to see their comments or responses hee-haw..."

To summarize, the overall mean of 3.94 revealed that Toondoo promotes collaborative e-learning to a high extent. It further disclosed that Toondoo serves as a platform that increases students' eagerness to collaborate and share their new ideas on the internet. The above results conform to the study of Tedre et al. [14] who contended that connectivity (environmental effects, Internet penetration, mobile networks, stability, and technical support, cost) is one of the factors affecting students' e- learning in various developing countries. Findings of the study also affirm the study of $\mathrm{Su} \&$ Beaumont [15] who posited that maximum learning happens when there is exchange of ideas and opinions, open discussion, collaborative construction and sharing of knowledge.

Table 2. Correlation Result between the Use of Toondoo and their Performance in EdTech 105A

\begin{tabular}{|c|c|c|c|}
\hline $\begin{array}{c}\text { The Extent of how } \\
\text { Toondoo Promotes } \\
\text { Collaborative E- } \\
\text { Learning }\end{array}$ & $\begin{array}{c}\text { Correlation } \\
\text { Coefficient } \\
\text { (r) }\end{array}$ & p-value & Remarks \\
\hline $\begin{array}{c}\text { A. Focus on task and } \\
\text { participation }\end{array}$ & .480 & .001 & Significant \\
\hline $\begin{array}{c}\text { B. Shared } \\
\text { Responsibility, } \\
\text { accountability, and } \\
\text { dependability }\end{array}$ & .292 & .055 & $\begin{array}{c}\text { Not } \\
\text { Significant }\end{array}$ \\
\hline $\begin{array}{c}\text { C. Communication } \\
\text { Strategies and } \\
\text { Information Sharing }\end{array}$ & .325 & .032 & Significant \\
\hline Overall & .484 & .001 & Significant \\
\hline
\end{tabular}

Likeise, this study also determined the influence of Toondoo on students' academic performance. This relationship was established using the Pearson r. It can be gleaned from Table 2 that only the parameter on "shared responsibility, accountability, and dependability" has no significant influence on the academic performance of the students. This is shown by the p-value of .055, which is greater than .05 level of confidence.

In contrast, the correlation results showed that the academic performance in EdTech 105B has a significant influence on the students': focused task and participation $(\mathrm{r}=0.480, \mathrm{p}=.001)$; and communication strategies and information sharing $(\mathrm{r}=.325, \mathrm{p}=.032)$. This means that the use of Toondoo influences students' performance. The result rejected the null hypothesis since p-value is less than 0.05 level of significance.

Furthermore, based on the FGD, results revealed that 37 out of 44 students found Toondoo to be fun, but quite challenging; 40 out of 44 students appreciated the dynamics of Toondoo making them inspired, participative and excited in class. This implies that students were able to sustain their interest in the course, which is requisite to improve their performance in the subject.

Generally, the use of Toondoo is significantly related to students' performance in EdTech105b. This signifies that the utilization of Toondoo affects the students' performance and its degree $(r=.484)$ of relationship is moderate. Moreover, it implies that as students' frequency on the use of Toondoo increases, their academic performance in EdTech 105B also improves.

These findings support the study of Unwin [16] who posited that innovative tool is a catalyst for educational development that supports and improve teaching. Thus, employing ICT tools, (e.g., Toondoo) students may be able to engage themselves in the practical and authentic learning that enhances their performance.

Table 3. Correlation Result between the Use of Toondoo and Students'attitude towards Collaborative E-Learning

\begin{tabular}{|c|c|c|c|}
\hline $\begin{array}{c}\text { The Extent of how } \\
\text { Toondoo Promotes } \\
\text { Collaborative E- } \\
\text { Learning }\end{array}$ & $\begin{array}{c}\text { Correlation } \\
\text { Coefficient } \\
(\mathrm{r})\end{array}$ & $\mathrm{p}$-value & Remarks \\
\hline $\begin{array}{c}\text { A. Focus on task } \\
\text { and participation }\end{array}$ & .485 & .001 & Significant \\
\hline $\begin{array}{c}\text { B. Shared } \\
\text { Responsibility, } \\
\text { accountability, and } \\
\text { dependability }\end{array}$ & .447 & .002 & Significant \\
\hline $\begin{array}{c}\text { C. Communication } \\
\text { Strategies and } \\
\text { Information } \\
\text { Sharing }\end{array}$ & .449 & .002 & Significant \\
\hline Overall & .614 & .000 & Significant \\
\hline
\end{tabular}

Table 3 shows the influence of Toondoo on students' attitude towards collaborative e-learning. Using Pearson r, the computations revealed that the employment of Toondoo had a significant effect on the following: focused task and participation $(r=.485, \mathrm{p}$-value $=.001)$; shared responsibility, accountability and dependability ( $\mathrm{r}$ $=.447, \mathrm{p}$-value $=.002)$; and communication strategies and information sharing $(\mathrm{r}=.449, \mathrm{p}$-value $=.002)$; since the p-values are less than 0.05 . Conclusively, the use of Toondoo significantly influenced the students' attitude towards collaborative e-learning since the overall $r$ 
of .614 denotes moderate correlation with a p-value of .000 .

Moreover, it implies that as the frequency of the use of Toondoo increases, the students' attitude towards collaborative e-learning becomes more positive. The result of this study affirms the argument of Liaw and Huang [17] who claimed motivation is the main ingredient that influence users' intention of collaborating using Internet technology. These findings also jibe with $\mathrm{Lu}$ and Yeh [18] claimed that collaborative e-learning delivers many enhancements to e-learning technology; it enables students to collaborate with each other and improves their learning efficiency. Furthermore, Carmichael \& MacEachen [19] highlighted that collaborative learning among youths is enhanced using online technologies; which enabled them to connect easily, and communicate effectively.

\section{CONCLUSIONS \& RECOMMENDATIONS}

In the light of the findings, the following conclusions were made:

1. Generally, the students have a "Positive Attitude" towards Toondoo as an innovative technique that enhances the e-learning of the pre-service teachers.

2. Toondoo promotes the collaborative e-learning of the pre-service teachers to a high extent.

3. The students' focused task and participation; as well as on communication strategies and information sharing on Toondoo had significantly influenced their grades in Ed Tech105.

4. The use of Toondoo significantly affects students 'attitude towards collaborative e-Learning.

In summarizing the qualitative data gathered based on the evaluation, it can be concluded that the utilization of Toondoo increases students' learning and their 21st century skills. It was also discovered that the integration of Toondoo produces higher academic achievement compared with traditional instruction; students learn faster and with higher retention with the aid of Toondoo. Likewise, students like exploring Toondoo and their attitudes toward learning are positively affected by the Toondoo usage; the use of Toondoo emerged as a promising strategy for low-achieving and low motivated students; and effective teacher workshop is a vital component for successful learning programs based on, or assisted by any technology innovations.

Additionally, data revealed that Toondoo is positively viewed by students, as it enhances their communication, creativity skills at the same time improves their academic performance. This finding is similar to the study conducted by [20] who employed quasi-experimental design or methodology. They found that students who were exposed to Toondoo tend to perform better. Similarly, the use of Toondoo was something very motivating for the students as far as learning is concerned [21]. Thus, teachers are encouraged to employ this technique as an enrichment activity for their students to gain diverse learning experiences that boost students' innovative skills. Nevertheless, this will necessitate effective preparation for mentors to address critical issues such as establishing appropriate rubrics and identifying the effective style of communication among students and teachers. Equally important is the development of students' 21st century skills. Based on the K-12 curriculum set by the Department of Education, these skills must be given priority because they will enable students to make intelligent decisions. The use of Toondoo is only one of the Web 2.0 technologies whereby teachers can: develop the higher order thinking skills (HOTS) of their students; encourage them to collaborate, appreciate new learning experiences; and finally sustain their interest in the subject. Undeniably, innovations have generated a new face for education style and added reason to adopt the new style of teaching with the use of blogging platforms, mobile technologies and other online freeware [22,23].

These conclusions are in congruence with the result of the study conducted by Malhiwsky [24] who stressed that Web 2.0 technologies must be employed by teachers to promote students' collaboration at the same time to improve their learning engagement and achievement. However, there were limited experiential studies supporting the reliability or validity of these innovations.

This research is a baseline study that tried to provide insights on how Toondoo promoted e-learning as it improves students' attitudes and achievement. As such, there were two major implications derived. First, teachers and students consider technology (e.g., Toondoo) as an important ingredient that enhances learning and performance. However, most of the teachers need to exert more effort in discovering other educational tools to substantially integrate and manage relevant tools that will advance the effectiveness of these innovations to the courses.

Secondly, the teachers have done their part in performing their sworn duties and responsibilities in teaching and innovating. Though teachers have available resources students perceived that there were insufficiencies in the integration and implementation of these tools to other courses.

In consideration with the interviews and FGDs, an inference is that students who show a positive attitude towards Toondoo have higher e-collaborative learning \& academic performance. The results further revealed that the students' e-collaborative learning is affected by their attitudes toward the use of Toondoo in the subject. Furthermore, this research indicates that Toondoo enhances students' e-collaborative learning and performance. Since empirical evidence have not yet existed to support the reliability and validity of Toondoo, the researcher can merely conclude as to its significant effect on students' attitude and performance. Other researchers may further conduct studies that determine other factors that students can gain using this approach. Likewise, do replication that determines the foundational sources intended for these integrations, or conducts the 
cost-benefit analyses of Toondoo that contribute to students' holistic learning.

The innovation introduced to students must emphasize a mechanism that ensures the addressing of students' learning needs. To achieve this, the study adopts an innovative approach so that access and benefits from the use of technology applications are provided to enhance their learning.

Strong evidence and knowledge from the research, observation, and evaluation were based on the principles that all students have the right to enhance their $21 \mathrm{st}$ century skills. To equitably meet the learning styles and needs of learners, the learning environment, processes and available educational tools and systems need to be adaptable and context appropriate.

As a practical consideration, this study was done to show innovative case technique for other universities and colleges for replication.

Based on the preceding findings and conclusions, it is however recommended that prospective research efforts may include studies designed to identify the effectiveness of Toondoo and its applications to students' learning. To verify the long-term significance of Toondoo and to address concerns associated with the criterion and predictive validity, future studies might include a longitudinal component in analyzing the level of $21 \mathrm{st}$ century skills of students who will employ Toondoo. Supplementary progression of this study may also include consultants or specialists to assess students' outputs, thus enhancing their content validity. To minimize threats to external validity, prospective studies may engage coordinated study efforts from various universities. To enhance internal validity, other researchers might regard revisions in the methodology dealing with other issues on validity.

\section{REFERENCES}

[1] Commission on Higher Education (CHED) Memorandum Order No 46, 2012

[2] Portugal, C.. Digital Games and Interactive Activities: Design of Experiences to Enhance Children TeachingLearning Process. International Journal of Modern Education and Computer Science, 8(12), 1, 2016.

[3] Kahiigi, Evelyn. A Collaborative E-learning Approach Exploring a Peer Assignment Review Process at the University Level in Uganda. Retrieved on 3 November 2013 from http://su.diva-portal.org., 2013.

[4] Baranauckas et al.. Daily Source Organization. Retrieved on March 8, 2012, from http://www.dailysource.org/about/impact\#.T4ri66waPpw., 2012.

[5] Karber, D. J. Comparisons and Contrasts in Traditional Versus On-Line Teaching in Management. Higher Education In Europe, 26(4), 533-536,2001.

[6] Green, K. C. Campus computing. The sixth national survey of desktop computing in higher education. Encino, CA Campus Computing. (ERIC NO. ED 394 383), 1996.

[7] Robles, Ava Clare Marie O. The Use of Educational Web Tools: An Innovative Technique in Teacher Education Courses. I.J.Modern Education and Computer Science, 1-7 Published Online November 2010 in MECS (http://www.mecs-press.org/), 2010.
[8] Salmons, Janet. Storytelling \& Collaborative E-Learning Resources for Educators. Retrieved on 5 November 2013 from http://www.vision2lead.com/Storytelling.pdf

[9] Pund, Maggie. New Factors Impact Stress in College Students. Northerner Online. Retrieved on 5 December 2013 http://www.thenortherner.com/news/2013/02/28/newfactors-impact-stress-in-college-students/, 2013.

[10] Lambropoulos, N, Culwin, N and Romero, Margarita. HCI Education to Support Collaborative e-Learning Systems Design. 2010. Retrieved on 5 November 2013 from http://elearnmag.acm.org/archive.cfm?aid=1858580

[11] International Society for Technology in Education (ISTE).Technology and Student Achievement - The Indelible Link, 2008. Retrieved on 3 November 2013 from http://www.k12hsn.org.

[12] Li, Lilian K.Y. A Study of the Attitude, Self-efficacy, Effort and Academic Achievement of City U Students towards Research Methods and Statistics. Discovery - SS Student E-Journal, 2012.

[13] Calmorin, Laurentina. Research and Statistics. National Bookstore, Philippines, 2010.

[14] Tedre, M., Ngumbuke, F., \& Kemppainen, J. Infrastructure, human capacity, and high hopes: A decade of development of e-learning in a Tanzanian HEI. Revista de Universidad y Sociedad del Conocimiento, 7(1), 7-20, 2010.

[15] Su, Feng and Beaumont, Chris. Evaluating the use of a wiki for collaborative learning. Retrieved 25 December 2013 from http://repository.edgehill.ac.uk, 2010.

[16] Unwin, T. ICT4D: Information and communication technology for development. Cambridge University Press, Cambridge, UK, 2009.

[17] Liaw, Shu-Sheng and Huang, Hsiu-Mei. A Study of Investigating Learners' Attitudes Toward E-Learning. 5th International Conference on Distance Learning and Education vol.12, Singapore, 2011.

[18] Lu, Lai-Chen and Yeh, Ching-Long. Collaborative ELearning Using Semantic Course Blog Volume 6, Issue 3, 2008.

[19] Carmichael, D., \& MacEachen, C. Heuristic Evaluation of the use of Blackboard \& Facebook Groups in Computing Higher Education. International Journal of Modern Education and Computer Science, Vol. 9 (6), 2017.

[20] Wilujenga, N. C. S., \& ju LAN, Y. Online cartoon in Mandarin Chinese teaching: A case study of a school in Indonesia, 2013.

[21] González, Alba Milena Velandia . Comics in ToonDoo and Collaborative learning, a visual literacy resource to evidence vocabulary learning with emphasis in action verbs in an EFL group of seventh graders. Retrieved on July 2017 from https://www.researchgate.net, 2016.

[22] Al-Hakeem, M. S., \& Abdulrahman, M. S. Developing a New e-Exam Platform to Enhance the University Academic Examinations: The Case of Lebanese French University. International Journal of Modern Education and Computer Science, Vol. 9 (5), 2017.

[23] Sangameswar, M. V., Rao, M. N., \& Kumar, M. S. Building a Natural Disaster Management System based on Blogging Platforms. International Journal of Modern Education and Computer Science, Vol. 9 (8), 2017.

[24] Malhiwsky, Dallas R. "Student Achievement Using Web 2.0 Technologies: A Mixed Methods Study". Open Access Theses and Dissertations from the College of Education and Human Sciences. Paper 58. Retrieved December 2011 from http://digitalcommons.unl.edu/cehsdiss/58. 2010. 


\section{Author's Profile}

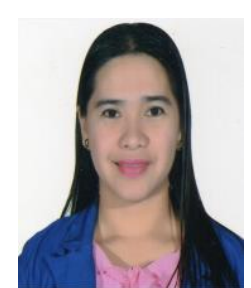

Ava Clare Marie O. Robles is an Associate Professor IV of Mindanao State University - General Santos City. She finished her Bachelor of Secondary Education degree at Mindanao State University - Marawi City. She obtained her $\mathrm{MA}$ in Education and Ph.D. in Education at Notre Dame of Dadiangas
Currently, she is the Research Coordinator of Mindanao State University College of Education and has been an International paper presenter in Thailand, Malaysia, and Japan. Last October 2016, she was invited as one of the Keynote Speakers in Indonesia. Likewise, her researches and articles were published in various International peer-reviewed journals.

Dr. Robles received several awards. Among her awards were: Outstanding Filipino Researcher in 2013, Distinguished Paper Award in Japan and Outstanding Filipino Research Leader in 2015.

University.

How to cite this paper: Ava Clare Marie O. Robles, "Evaluating the use of Toondoo for Collaborative E-Learning of Selected Pre-Service Teachers", International Journal of Modern Education and Computer Science(IJMECS), Vol.9, No.11, pp. 25-32, 2017.DOI: 10.5815/ijmecs.2017.11.03 